\title{
DIGITAL TRAUMA: THE REALITY AND THE MEAN WORLD. MEDIA COVERAGE OF BLACK LIVES MATTER PROTESTS DURING COVID-19 PANDEMIC IN THE USA
}

\author{
Mykaila Young \\ (iD) orcid.org/0000-0001-6183-0284 \\ The School of Global Public Health \\ New York University, United States
}

\begin{abstract}
This article seeks to establish to what extent does eyewitness user generated content influence social movements and feelings associated with vicarious/secondary trauma. Working with a sample of perspectives from activists, reporters, nurse practitioners, literary texts, and media articles this article explores the working hypothesis that eyewitness news and media narratives both play a role in cultivating environments of fear, mistrust, etc. that lead to vicarious/secondary trauma with a focus on the recent \#BlackLivesMatter protests in the USA in June 2020. This article builds upon previous research facilitated by the Dart Center for Journalism and Trauma within the theoretical framework of George Gerbner's Mean World Syndrome that focused on the influence of effects of violent media on individuals' attitudes. This article explores the similar effects that the digital eyewitness uncensored viral video of George Floyd's death had in producing feelings associated with vicarious/ secondary trauma among a sample of viewers that were directly involved in the nationwide protests during the global pandemic in America. The value of the article is twofold: it presents up to date research material obtained while conducting interviews with journalists who covered the protests and activists involved with the current social movements in America; it highlights the challenges to broadcasting for reporters and newsroom workers during the COVID-19 pandemic. The results of the interviews show that nearly all the respondents associated distressing content with feelings and emotions related to trauma induced anxieties and fears as a result of eyewitness media. Positive news coverage was reported as having a positive effect that encouraged people to understand the historical context of the Black Lives Matter movement. Most of my interviewees found distressing images "numbing" or too familiar. The article shows the media consumers' feelings developed as a result of "virtually inescapable" graphic content.
\end{abstract}

Keywords: eyewitness media, USA, reporters, \#BlackLivesMatter, COVID-19, trauma, digital trauma, graphic content 
This article seeks to establish to what extent does eyewitness user generated content influence social movements and feelings associated with vicarious/secondary trauma. Working with a sample of perspectives from activists, reporters, nurse practitioners, literary texts, and media articles this article explores the working hypothesis that eyewitness news and media narratives both play a role in cultivating environments of fear, mistrust, paranoia et. that lead to vicarious/secondary trauma with a focus on the recent protests. This article builds upon previous research facilitated by the Dart Center for Journalism and Trauma within the theoretical framework of George Gerbner's Mean World Syndrome that focused on the influence of effects of violent media on individuals' attitudes. Mean World Syndrome asserts that viewers who are exposed to violence related content can experience increased fear, anxiety, pessimism, and heightened state of alert in response to perceived threats. This is because media (namely television) consumed by viewers has the power to directly influence and inform attitudes, beliefs, and opinions about the world. This article will explore the similar effects that the digital eyewitness uncensored viral video of George Floyd's death had in producing feelings associated with vicarious/secondary trauma among a sample of viewers that were directly involved in the nationwide protests during the global pandemic in America.

\section{Nationwide Protests During the Global Pandemic}

Thousands of people marched into American streets during the coronavirus pandemic in 2020 to protest against what they saw in a viral video, disseminated in the internet, which captured the death of an African-American man named George Floyd, killed by a police officer who ignored the calls for help from a man who begged "I can't breathe". These words were heard after his death by crowds of people who disregarded the safety measures implemented by the US in 2020 to slow the spread of the novel coronavirus SARS-CoV-2 which lead to global pandemic in the early months of this year.

Nationwide protests for George Floyd began on the 25th of May 2020 shortly after the video of officer Derek Chauvin was filmed kneeling on George Floyds neck, while handcuffed, as he continuously pleaded for air. Mainstream media outlets, activists, social media influencers, and content viewers from both sides of the movement began posting and demanding justice for his death. The headline that CNN Journalist, Chris Cuomo (2020) used to describe the aftermath of Floyd's death was that America is "a tale of two cities", alluding to the division of one side majority and the other side the minority. The New York Times headlined " 8 Minutes and 46 seconds: How George Floyd Was Killed in Police Custody" (Bogel-Burroughs 2020). ABC News Writer, Jill Lawless (2020) referenced George Floyd's death "an American tragedy with global echoes".

Global was also the COVID-19 pandemic. The official scientific name for the novel coronavirus is severe acute respiratory syndrome coronavirus 2 (SARS-CoV-2). 
The outbreak of the highly infectious disease, renamed COVID-19, in China in 2019 lead to a global health crisis in 2020 when the virus spread to all continents, affecting almost 24 million people around the globe and killing more the 817 thousands, according to WHO statistics (published on the 25th of August 2020).

On the 30th of January 2020, The World Health Organization declared the coronavirus outbreak a public health emergency of international concern. In mid-March it was a considered a pandemic straining healthcare systems in almost every country that struggled with implementing measures to slow the spread of the virus. By the 7th of April 2020, the U.S. reported more than 2,000 deaths in a single day for the first time, according to a count maintained by Johns Hopkins University at the time (Thornton 2020). President Donald Trump issued restrictions and quarantine protocols to Americans that prohibited social gatherings of more than 10 people for 15 days in attempt to slow the spread of the virus. These restrictions extended through June as the cases continued to rise. Health experts feared the lack of social distancing at demonstrations for George Floyd would lead to an influx of the coronavirus (Thornton 2020).

In addition to the mandate for citizens to follow social distancing protocols, the same rules applied to reporters and newsroom workers. Reporters on the frontline were still required to produce content for daily segments within the required social distancing protocols to mitigate the spread of the virus among each other.

These concerns were expressed, among many other issues, in the interviews I conducted as part of my research on the traumatic impact of digital media contents, the excerpts of which I present in the article.

\section{Methodology}

The cognitive value of this article is up to date research material obtained while conducting interviews with journalists, activists, students and nurse practitioners directly involved with the current social movements in America. This report contains five distinct sections. The report begins by explaining the state of America in the early stages of coronavirus. Followed by the experiences respondents to my survey had with viewing the uncensored eyewitness video of George Floyd's death that led to nationwide protests. I also highlight the challenges to broadcasting for reporters and newsroom workers (that participated in the survey) during the COVID-19 pandemic. I illustrate throughout the article the cognitive value of this article through the use of interviews and the theoretical framework of George Gerbner's Mean World Syndrome theory to showcase the correlation between the role that digital storytelling (through eyewitness media) plays in producing trauma related anxieties and fears i.e. paranoia, anxiety et. among participants. I later explore the historical context to showcase why movements like Black Lives Matter are broadcasted online, at high frequencies, through eyewitness media that participants on both sides reported to be related to feelings of trauma. This is followed up by the discussion of the controversy between conflicting media narratives surrounding George 
Floyd's death. I conclude this report with recommendations from the Dart Center for Journalism and Trauma for individuals that feel impacted by eyewitness news.

As with the survey, my objective was to share the perspectives of activists, reporters, and students that were personally impacted by the viral video of George Floyd during the coronavirus outbreak. In addition to the casing point, I wanted to see if any trauma related feelings developed as a result of "virtually inescapable" graphic content; I was equally invested in understanding if media framing/narratives influenced any of the interviewees perception of the world they live in that resulted.

During the COVID-19 pandemic lockdown in June 2020 I conducted several online interviews with reporters and activists: M. Francisco, Marissa Silver, Léonide Gofin, Maeve Glackin-Coley, Ashley Brown, Jen Mueller, and an interviewee who wanted to remain anonymous, for personal reasons.

M. Francisco ${ }^{1}$ is a community organizer, anti-oppressive educator and researcher who has organized protests and sit-ins in Oklahoma for the past 3 years.

Marissa Silver ${ }^{2}$ is a News Producer in Louisville, Kentucky. She has worked in news since 2005. She worked professionally in the field for eight years, five years which were spent as an on-air reporter in Anchorage, Alaska at FOX News.

Léonide Gofin ${ }^{3}$ is a digital marketing content creator familiar with the influence that digital mediated content can have on influencing positive or negative emotions. Maeve Glackin-Coley ${ }^{4}$ is a youth activist that has been a part of the social justice movement since 2016. Ashley Brown ${ }^{5}$ graduated from the University of Washington with a degree in Communications and Political Science. B.M graduated from Howard University with a degree in nursing and health science. She is a registered nurse in dialysis and infectious diseases in Newark, NJ.

1 M. Francisco received his B.A in African and African American Studies and Political Science with a minor in Women's and Gender Studies and International Studies from the University of Oklahoma. He has organized protests and sit-ins in Oklahoma for the past three years. His inspiration comes from wanting to see radical change to the systems, institutions, and behaviors that inflict grave violence upon marginalized people across the world. He is the Co-founder and Co-Executive Director of Foundation for Liberating Minds, a nonprofit working to dismantle systems of oppression through transformative education.

2 Marissa Silver has been producing news for 2 1/2 years in Hazard Kentucky. She received her B.A in Journalism at Indiana University.

3 Léonide Gofin is a French native born in Paris. She lived on the island of Guadeloupe during her teenage years where she experienced a cultural shock and discrimination being a French native at schools where students spoke a different language. Currently, she is pursuing her M.A in Digital Marketing at Skema. Her interests include digital marketing as a form of art to tell stories of society through video content.

4 Maeve Glackin-Coley's inspiration for activism was influenced by her parents who have been vocal about social justice issues. She is inspired by youth and documentary makers in particular. She is a member of the Greater Tacoma Community Foundation's Youth Philanthropy Board.

5 Ashley Brown is currently working in the marketing industry and has a passion for Diversity and Inclusion. Her aspiration is to help corporate America better understand how they can improve equality and equity in the workplace. 
Jen Mueller ${ }^{6}$ is an American television and radio sports broadcast journalist. She has been in the broadcasting industry 20 years, first as a producer before moving on camera. She has worked on TV for 14 years.

During the interviews, my respondents shared their feelings regarding what they had seen and experienced when people went out into the streets shouting in unison: "I can't breathe". The impact of George Floyd's last words and sounds recorded in the viral video will be discussed later.

\section{Theoretical Framework: Mean World and Eyewitness Trauma}

In 1968 George Gerbner established the Cultural Indicators Project which was a pioneering analysis of the influence of television on people's attitudes and perceptions of the world. This project documented the trends in television content and how these changes affect viewers' perceptions of the world. During the Cultural Indicators Project, Gerbner defined Mean World Syndrome as the phenomenon in which people who watch moderate to large amounts of television are more likely to perceive the world as a dangerous and frightening place (Jamieson, Romer 2014, p. 32; see also: Gerbner, Gross 1976). In 2010 The Media Education Foundation filmed a documentary titled "The Mean World Syndrome: Media Violence \& the Cultivation of Fear" summarizing the work of G. Gerbner and others concerning the effects of violent media on people's attitudes, opinions, and beliefs. The perspective outlined was that violence has become so familiar to us that we are often as blind to its all-encompassing presence as a fish is to water. According to Gerbner, the entire media context is what matters, how one kind of story or program blended into another to create and reinforce a distinct view and sense of the world (see: Gerbner, Morgan 2010, p. 6). Gerbner explored how media messages impact the way that consumers of media messages perceive the real world (Vinney 2020, p. 1).

The article discusses the case of George Floyd and public protests after his death. The widespread frequent circulation of videos of police killings, racist encounters between American citizens and frequent reminders through digital media of the "dangers" of living in America have proved to have lingering consequences for online viewers. With rapidly developing technology and the rise of social media, the public sphere today looks vastly different than it did even 20 years ago. Rather than needing to set aside time to listen in on national and transnational conversations about race and oppression et via evening news, increased access to the Internet and the ability to read and contribute to discourses on social media via one's cell phone allows individuals to engage in participation in the public sphere throughout their daily activities that did not exist decades ago.

6 Jen Mueller graduated from Southern Methodist University with degrees in broadcast journalism and public policy. 


\section{Crisis Coverage and Social Distancing in 2020}

Because of the coronavirus pandemic US citizens were obliged to follow social distancing protocols. The same rules applied to reporters and newsroom workers:

We are required to take separate vehicles. Even with the protests and needing security, the security detail was required to take their own vehicles to scenes and meet our crews there. If you had to ride in a car with another co-worker you must wear a mask', said Silver (2020).

Despite mandatory social distancing protocols, news stories were still required to be produced in non-traditional ways. Apps were used to communicate for news segments among reporters and also for interviews:

I have the ability as a producer to see monitors in the control room as if I were there through this app. We use a different app that allows me to talk to the director, master control room workers, my anchor, and the meteorologist just as if I were in the control room even if I am at home. Interviews are conducted over Zoom instead of in person (Silver 2020).

\section{The Black Lives Matter Movement}

The story of the historical movement, Black Lives Matter begins with the death of Trayvon Martin, 17, shot and killed in 2015 by officer Derrick Wilson in Sanford, Florida. Unarmed, with his hands in the air, Trayvon Martin was killed, and the officer was acquitted. This sparked the beginning of the nationwide movement calling for justice and police accountability for Black lives taken unjustly and without consequence in America. The Black Lives Matter movement seeks to raise consciousness to the injustices of police violence that African Americans have historically experienced since the abolition of slavery. The movement mobilizes, informs, and works to dismantle systemic racially biased policies that protect police officers from consequences for rogue infractions. In their noteworthy study on police brutality and the origins of the Black Lives Matter movement, Chaney and Robertson write that 'the murder of unarmed Black children signals to them early on in life that members of law enforcement are to be regarded with suspicion and fear' (Chaney, Robertson 2015, p. 63).

George Floyd was suspected of passing a counterfeit $\$ 20$ bill at a convenience store in Minneapolis, when police were called. Floyd was restrained with handcuffs with an officer's knee to his neck that later resulted in his death.

The video of George Floyd's death for many respondents to the survey, was not the first encounter that individuals participating in the public sphere had with digitalized fatal police encounters online. In 2014, Michael Brown, 18, was shot and killed 
by officer George Zimmerman in Ferguson, Missouri. Tamir Rice, 12, was shot and killed in 2014 by an officer in Cleveland, Ohio. Freddie Gray, 25, was killed while under the care of law enforcement in 2015. Alton Sterling, 43, was killed by police in Baton Rouge, Louisiana in 2016. Eric Gardner, 32, died as a result of a chokehold during an arrest in New York City in 2017.

The Black Lives Matter movement asserts when a murder occurs, the same level of accountability should exist for the general population and members of law enforcement, and that Black lives should have the same value as that of non-blacks. In their report Chaney and Robertson write that the murder of unarmed Blacks carries forward and solidifies the racist legacy of citizen slave patrols that were initiated during slavery (Chaney, Robertson 2015, p. 51).

In the South, lynching was such an effective method of policing the activities of African American men from 1880's into the civil rights era.

John W. Fountain (2020), author at The Chicago Sun Times referred to the murder of George Floyd as a 'modern day lynching'. Twitter users concurred by tweeting messages:

May 30, 2020: 'Every news story, every person should say George Floyd's lynching not just death'.

June 8, 2020: 'Emmett Till's lynching ignited a civil rights movement. Historians say George Floyd's death could do the same'.

June12, 2020 'His Lynching was caught on camera and broadcasted all over TV'.

July 11, 2020 'George Floyd didn't just die. It was not just a death, or even just a murder, this $100 \%$ is a lynching. The very definition of a lynching' (Twitter 2020).

The reference to George Floyd's death as a modern-day lynching reminded some of the respondents of the unfairness and continuation of systematic racism and unlawful killing of Black Americans. Arguably, police brutality may not be the leading issue plaguing Black communities across America, the effects of the coverage and history of violence give the perception and feeling as though it is. CNN journalist Amir Vera reported under the article headline "Chicago sees deadliest Memorial Day weekend in four years with 10 killed and 39 injured in shootings" within a day of Floyd's death (Vera 2020).

One respondent I interviewed in my survey, who is based in France and experienced the video virtually as well, felt shocked the police officers in question felt powerful enough to murder a man in front of eyewitnesses and cameras:

These policemen were fearless of the consequences of their actions which shows the oppression citizens suffer from. Watching the entire video of George Floyd's death was difficult. I could feel the pain when he was screaming and suffocating, especially when he called out for his mom. At first, I wondered why people around did not intervene to help George Floyd. But then I remembered that the police are more violent in America than in Europe and that other people could also be hurt for trying to intervene. I think these policemen could have 
easily pulled out their guns if people intervened, which is not such an easy thing to do in France. This is why I think the issue of police violence and gun violence is much more of an issue in America than in France, said L. Gofin (2020).

Another interviewee recalled the experience of the video:

Watching someone's last breaths is never an easy experience. Watching as they yell out telling their killer that they cannot breathe, yelling for their mother, is an indescribable level of pain. Knowing that the person who robbed them of their breath likely will not face any consequences nor accountability and that another Black family will have to live without their loved one. It is just so terribly sad and the worst reminder that this country has always taken Black lives too soon as a result of institutional racism (Francisco 2020).

A news producer explained the shock of terror she felt when confronted with uncensored footage of her station's news crew and station on the first night of the protests where tear gas and rubber bullets were used by police as reporters covered the events:

It was emotionally challenging to see my co-workers out in the field during the protests when gun shots went off behind them or the glass on our building was broken and tear gas thrown inside. I was very shaken when I saw a reporter at another station in my city shot nearly point blank with pepper balls by a police officer while she was live on air. That shook me because I used to be a reporter so I could only imagine what it would have been like to have that happen to me. The look in the officer's eyes through his face shield was chilling, said news producer M. Silver (2020).

Activists who were interviewed believed public awareness of police killings of unarmed Black Americans has been intensified by social media broadcasting of high-profile deaths i.e. George Floyd, Michael Brown, Eric Gardner, Trayvon Martin, among others, that respondents felt were drowned out by the media and news reports that shifted focus from the protests back to the rising cases of the virus. This frustrated activists and led to a desire to continue to remind the public of the injustices among marginalized communities resulting in more exposure to secondary trauma generated by users although some found the sharing of such experiences unhelpful:

The cops who murdered George Floyd were not arrested because other cops saw the video, they were arrested because we the people saw the video. I do not believe that sharing the images and videos of people's last moments is helpful in regards to awareness and I know that for Black people it is an incredibly dark experience to watch and see them berated on the TV screen and throughout social media, said M. Francisco (2020). 
The unlawful deaths of G. Floyd, T. Martin, E. Gardner, A. Sterling and other Black men killed by the police have circulated around the public sphere on social media platforms i.e. Facebook, Twitter, Instagram, among others.

\section{Traumatic Eyewitness Media}

The correlation between the impact viewing traumatic eyewitness media has upon the mental health and feelings associated with trauma as a result was studied by Sam Dubberly, Elizabeth Griffin and Haluk Mert Bal (2015) - researchers whose impressive report is recommended by the Dart Center for Journalism and Trauma resources. Their study focused on vicarious/secondary trauma as a primary issue to eyewitness media on the digital frontline. The intuitive link between social media and activism is its potential for mobilizing new activists and telling the stories of individual realities.

Secondary Traumatic Stress (STS) is a concept that was developed by trauma specialists Beth Stamm, Charles Figley (1995) and others in the early 1990s that sought to understand why service providers seemed to be exhibiting symptoms similar to Post Traumatic Stress Disorder (PTSD) without having necessarily been exposed to direct trauma themselves (O'Handley 2017, p. 1). Vicarious trauma (VT) and Secondary Traumatic Stress (STS) are frequently used interchangeably to refer to the indirect trauma that can occur when an individual is exposed to difficult or disturbing images and stories second-hand (O'Handley 2017, p. 1). In the article "Tools to Reduce Vicarious/Secondary Trauma and Compassion Fatigue" Amanda O'Handley found that this can occur by viewing graphic news reports, gruesome or frightening television shows and various other media. It can also affect civilians who do not work in high-trauma fields but are deeply impacted by stories they are exposed to i.e. graphic news accounts, a friend sharing details of a traumatic event they experienced etc. In her report O'Handley (2017, p. 1) contributes that secondary or vicarious trauma is caused by an indirect exposure to trauma: you are not in actual danger; you are not at the scene of the traumatic event seeing first-hand the results of a shooting rampage or an accident. Instead, those stories are described verbally, in writing or through audio or video recordings. Sound matters.

\section{I can't breathe: Sound and Trauma}

Sound was reported, by Dubberly, Griffin and Mert Bal (2015, p. 6), as one of the most distressing elements of working with eyewitness media: the example of children in distress; hearing violence; the utterance of last words; people pleading for their lives and the screams as they die was used to describe the impact that sound can have with viewing traumatic content.

For some participants in my study it was the sound of Floyd's pleading for air when he said, "I can't breathe" in the early portion of the video that made feelings 
of pain, sadness, anxiety etc. "virtually inescapable". One activist reported not being able to watch the full video because of feelings associated with "numbness".

What some respondents found distressing about eyewitness media was the normalization of online content similar to the fatal police encounter George Floyd had with the Minneapolis Police Department. One youth activist reported feelings associated with compassion and fatigue as a result of too much exposure of distressing race-related content. "You are numbed to the pain, and as an American, the videos of police brutality barely shock you anymore. It's like every month there's a new video to watch", Maeve Glackin-Coley (2020) said.

Michael Morgan, Professor of Communication at the University of Massachusetts, suggested that becoming accustomed to a narrative in a given cultural environment is like a fish that does not know that it is swimming in water because it has never experienced anything else (Gerbner, Morgan 2010, p. 6). The frequent message of violence as part of the cultural environment in America through uncensored eyewitness media contributed to feelings and anxiety of "same sad movie over and over again" as one activist described. "I see traumatizing videos almost every day online," another activist wrote.

The intensified impact of unexpected horrific content was described by a student-activist Ashley Brown (2020) as "virtually inescapable" due to the growing sensationalism of eyewitness news as a form of storytelling and activism.

Trauma related anxieties are intensified in the new digital age of media. The transition from television to popular social media platforms i.e. Instagram and Facebook can be considered as having the same, if not the heightened effect, based on my surveys.

Social media allows for videos and images similar to the one captured of Minneapolis police officers killing 46-year-old Black resident George Floyd, to also be "virtually inescapable". If online content cannot be escaped trauma becomes more accessible when viewed, re-visited, and shared online at higher frequencies from smartphones than normal traditional television broadcasts would have allowed. Case in point: resulting in anxiety and fear, in a mean and dangerous digital world. A. Brown described her experience of the attempts to avoid the uncensored video out of fear the content would be too distressing or traumatizing:

I chose not to watch the video of George Floyd which was more difficult than I thought it would be due to senseless posting of it all over the internet. I think the posting of someone's life being taken away from them should come with a graphic warning disclaimer at the very least, which was not always the case (Brown 2020).

In the report "Making Secondary Trauma a Primary Issue: A Study of Eyewitness Media and Vicarious Trauma on the Digital Frontline" (Dubberly, Griffin, Mert Bal 2015, p. 29), sound was described as making the greatest impact of distressing content. The impact of Floyd's last words and recorded sounds moved internet users so much they went out into the streets. Audio was reported to be just as bad, or even worse than witnessing the violence itself. The audio throughout the video 
consists of Floyd pleading for air and eyewitnesses begging the officer to remove his knee from the man's neck. My interviewees found the sound unbearable and horrifying to endure.

Each of the respondents involved in my survey expressed one or more feelings associated with vicarious and/or secondary trauma after viewing the eyewitness digital content of George Floyd's death. When participants were asked to describe the experience of watching the full video of George Floyd's death, the responses were as followed, based on each individual experience with the uncensored eyewitness content: "I could not watch the video of George Floyd's murder because it was too painful. I tried to channel my anger into immediate action" - this is how M. GlackinColey (2020) expressed her feelings associated with this graphic eyewitness video.

\section{Storytelling as a Potential Change Agent in Activist Movements}

Gerbner theorized that individuals that frequently viewed television highlighting violence, became fearful of the world, believing that crime and victimization were rampant (see also: Vinney 2020, p. 1).

Hashtags \#Am I next? were described as initial reactions to Floyd's death. One Facebook User wrote: “Last night, I slept in my son's room on the floor, heavy-hearted about the wicked murder of \#GeorgeFloyd and how that easily could have been my beloved boy-complying by dying". The expressions of pain, anger, hopelessness, and chaos became a relevant part of mainstream news story following Floyd's death that both mobilized and divided people. When journalists started to report on what Internet users were posting online and the sense of togetherness through the form of hashtags related to the protest and the demand for justice: \#GeorgeFloyd, \#Icantbreathe or \#blacklivesmatter contributed to the changes in media frames and turning points of the movement. "It's just so terribly sad and the worst reminder that this country has always taken Black lives too soon", said M. Francisco (2020).

The importance of eyewitness accounts as a form of activism and storytelling with the pursuit of justice at the heart of a given social movement, was described by activists involved in the survey as a call to action for better ways of telling the stories of the oppressed. Immense pressure to report was underlined by Television Broadcaster Jen Mueller who explained that:

The 24/7 news cycle creates tremendous stress and pressure for reporters and broadcasters to continue the flow of information. When you have to tell the same story multiple different ways, you have to keep finding new angles and it's one of the reasons you see different "experts" sounding off of every topic. Those experts need to sound different from each other so they can actually contribute to misinformation. I would almost say there is a quality control problem in the media. It's not that journalists aren't working hard, it's the pressure for viewers in a $24 / 7$ news cycle that leads to content that isn't as deep, rich or as informative as it could be (Mueller 2020). 
The stories the media told and the images that were portrayed, intensified feelings of fear, anger, paranoia et. among a sample of viewers that in the beginning of the pandemic, before the protests, had already begun experiencing. CNN was reported by interviewees as being the most common news source to receive updates on the development of the virus, protests and other news information compared to other media outlets. However, the narrative discourse i.e. by CNN in the early stages of the global pandemic were regarded by interviewees as confusing, misinforming, and one respondent described as "incredibly xenophobic and racist towards China". Registered Nurse, B. M., said:

The media's view of the COVID-19 pandemic in the beginning was very relaxed at first and then all of sudden it was this huge panic. The way the media showed shoppers buying up everything in the store as far as toilet paper, hand sanitizers and disinfectant spray in bulk and seeing many families without the opportunity to do so was disheartening (Registered nurse 2020).

The challenge to broadcasting and the tremendous stress and pressure for reporters to continue the flow of information during COVID-19 and the protests that a TV journalist J. Mueller, regarded as the biggest challenge to broadcasting during the pandemic, were exaggerated, when 24/7 coverage of both sides of the protests required around the clock updates. CNN reported demonstrations as largely peaceful in initial headlines describing the protests. Headlines remained neutral until instances of violence among protesters that clashed with law enforcement and stores that were looted and burned were reported. KTBS channel three news contributors headlined, "Small businesses across America were struggling to survive. Now they face a new threat" (Wiener-Bronner, Kavilanz 2020). While CNN coverage in the above article focused primarily on testimony of business owners affected most by the looting during the protests, no clear distinction was made between those protesting and those who were believed to have infiltrated the movement. Few regarded the media's coverage as accurately representing those involved in the movement. This led to increased Facebook sharing of looting videos to undermine the media narrative protesters were looting and responsible for the criminal activity. The more the videos were shared of the violence, theft and anarchy the more participation and chaos ensued as a result: "The media paints it as a black vs white issue, but it is not. It is everyone vs racism. It differs from what I see online because online I see more sides to the stories", said Glackin-Coley (2020).

The vast majority of interviewees across sectors spoke of the need for better representation in the media concerning experiences of Black people outside of times of crisis and accountability for injustices so some may step away from the perception it will always be a mean world and in order to survive it is necessary to be proactive and share and be the storytellers through eyewitness accounts. This need was an important factor which to some extent helped to mitigate feelings of trauma, paranoia, fear, anger et for some. For example, one activist felt: 
The media is often unable or unwilling to understand power dynamics when talking about forces of systemic injustice and those who fight against it. This leads to tainted coverage of rightfully angry protesters labeled as thugs and criminals, putting them on a level playing field as the institutional racism deeply entrenched in policing. The conversation quickly shifts from the state violence of police forces to the protesters who are demonstrating in what the media deems as the incorrect way to display our just anger. Truth is, there will never be a correct way to protest against racist systems in this country because those same systems are upheld by so many institutions, including American media and journalism (activist who wanted to remain anonymous 2020).

When one feels there is accountability to some degree - it helps, to some extent, to mitigate traumatic impact of eyewitness news because they feel less inclined to share and repost contradictory stories even if it is disheartening and distressing for some. What we see matters. Representation matters because it influences what we do and how we feel and the trauma that is then collectively shared as a direct result according to interviewees when asked about the lack of accurate representation and negative depictions.

M. Francisco, Organizer and Activist said:

The content in mainstream media suggests that America does not value the lives of Black individuals as much as they value the lives of white individuals. The reality is America has ignored and continued to build upon a racist history. America likes to call itself the greatest country, the most powerful in the world, but the media shows how far we truly have to go (Francisco 2020).

When the same interviewee was asked what it feels like to live in America and constantly see images and videos of police brutality and race related incidences:

Traumatic. Simply traumatic. Knowing that those images could be you, or your brother or sister or sibling or mother or father or cousin or friend or partner or just a Black person deserving of life who this society dehumanizes to the point of death. I do not believe that sharing the images and videos of people's last moments is helpful in regard to awareness (Francisco 2020).

In 2020, the narrative of black criminality in media environments resulted in division among activists and political commentators i.e. Candace Owens, during nationwide marches to demand peace and systemic change. George Floyd was regarded as "Gentle giant" in the CNN report (Ebrahimji 2020). CNN Analyst, Stephen Collison, focused on the legacy of Floyd that echoed across the globe (Collinson 2020, p. 1). Murals were painted to honor his death.

In their examination of the fatal shootings of unarmed Black people by police, Chaney and Robertson (2015) suggest that media characterizations of Black men as violent criminals contribute to the problem of police brutality and racism.

For activists like M. Francisco (2020) George Floyd's criminal background bore no ground in whether or not his death should have been protested in: 
It is nonsense, a distraction, and a despicable assertion. George Floyd was a human being who deserved life. Like we all do. It matters not what he did in his past, no one deserves to be killed by the police. The criminalization of Black people is incredibly harmful and violent and is a huge reason we are still stuck in the place we are and have progressed so little in regard to race and racism (Francisco 2020).

Conservative political commentator, Candace Owens' opposition to the narrative surrounding Floyd's death was published by contributor Elle Reynolds in the federalist media publication. This led to debates and division online from both sides of the movement:

Everyone is pretending that this man lived a heroic lifestyle. We are embarrassing in that regard. Nobody wants to tell the truth in Black America. Our biggest problem is us [...]. Not every Black American is a criminal. Not every Black American is committing crimes. But we are unique in that we are the only people that fight and scream and demand support for the people in our community that are up to no good (Reynolds 2020).

CNN journalist John Blake wrote that the Floyd video could lead to concrete changes in police culture. All four Minneapolis officers who were filmed arresting Floyd were arrested and charged in his death. The Minneapolis City Council pledged to defund and dismantle the city's police department in the wake of Floyd's death (Blake 2020).

\section{Eyewitness Media, Digital Environment and Vicarious Trauma}

While viewing some surprising and unexpected traumatic eyewitness video is inevitable due to the nature and framework of social media there are steps individuals can take to prevent, for example, the negative emotional effects of vicarious/secondary trauma. Marissa Silver, woke up and found pictures of her station's windows being broken and smoke bombs being thrown in her boss's window, she found online group therapy sessions with colleagues to talk about the experiences helped more than not addressing the incidents and moving on to the next story:

I learned during that incident the few people who were in the station that night had to be evacuated to our station's basement to be safe. We ended up starting 11 p.m. newscast later than usual because of the evacuation. It took me a while to get past the event of the reporter at the other station being shot at by police with pepper balls. The reporter directly affected, wrote a Facebook post about her experience several days later and it helped me to know she was doing okay emotionally and getting help. But that video was so upsetting for me to watch. Our boss also spent time during those days to talk to us in our meetings on Zoom 
to make sure we were doing okay and our company organized for us to do group online therapy sessions with smaller groups of our co-workers on Zoom and that helped too (Silver 2020).

For individuals that feel impacted by eyewitness digital media or notice signs related but not limited to vicarious/secondary traumatic stress, the Dart Center for Journalism and Trauma included tips for identifying and managing trauma. Helpful resources can be found at the Dart Center website (https://dartcenter.org/), together with the report "Making Secondary Trauma a Primary Issue: A Study of Eyewitness Media and Vicarious Trauma on the Digital Frontline" published in 2015.

Journalists, editors, producers and media workers should remember the most important things about dealing with traumatic digital media content.

Be aware that you and your colleagues are at risk of vicarious trauma as a result of working with distressing eyewitness media content. Educate yourself about vicarious trauma and PTSD and learn how to recognize symptoms [...]. Recognize that it is entirely normal human reaction to experience negative emotions as a direct consequence of viewing traumatic images eyewitness media content, in particular when one views such images on a regular basis and for prolonged durations. If you are experiencing negative emotions or feel that you are displaying symptoms of vicarious trauma do not feel guilty and/or ashamed. Understand that you are only human. You are not alone in experiencing such feelings. Be aware that working with distressing eyewitness media content can lead to trauma (Dubberly, Griffin, Mert Bal 2015, p. 61).

\section{Conclusion}

I found that nearly all the respondents to my survey associated distressing content with feelings and emotions related to trauma induced anxieties and fears as a result of eyewitness media. Positive news coverage was reported as having a positive effect during the protests after George Floyd's death that encouraged people to understand the historical context of the Black Lives Matter movement. Most found distressing images "numbing" or too familiar. Some found social media to be a necessary tool to put "real" images in the public sphere as a response to mainstream media "drowning out protests and the movement". The frequent message of violence as part of the cultural environment in America through uncensored eyewitness media content posted online at high frequencies contributed to feelings within the scope of anxiety, paranoia, fear and sensitivity to encounters with law enforcements and non-supporters of the social movements.

While not all activists and social media users experience trauma, the sample of individuals that responded to the survey exhibited feelings associated with anxieties and trauma. When one feels there is accountability to some degree - it helps, 
to some extent, to mitigate traumatic impact of eyewitness news because they feel less inclined to share and repost contradictory stories even if it is disheartening and distressing for some to view. What we see matters. Representation matters because it influences what we do and how we feel and the trauma that is then collectively shared as a direct result according to interviewees when asked about the lack of accurate representation and negative depictions.

Reporters that participated in the survey found that cultivating a safe space through organizing meetings and groups to share experiences and hardships among co-workers whether digital or in-person were helpful in regards to reducing anxiety among other feelings that were associated with vicarious and secondary trauma. The vast majority of interviewees across sectors spoke of the need for better representation in the media concerning experiences of Black people outside of times of crisis and accountability for injustices so some may step away from the perception that it will always be a mean world.

\section{Bibliography}

Blake J. (2020). The George Floyd protests are sparking a surprising debate in black America. CNN, 4.06.2020 [http:www.cnn.com/2020/06/04/us/protests-black-americans-debate-blake/ index.html; 12.07.2020].

Brown A. (2020). Personal communication.

Bogel-Burroughs N. (2020). 8 Minutes and 46 Seconds. New York Times, 1.06.2020 [https://www. nytimes.com/2020/05/31/us/george-floyd-investigation.html; 12.07.2020].

Chaney C., Robertson R.V. (2015). Armed and Dangerous? An Examination of Fatal Shootings of Unarmed Black People by Police. Journal of Pan African American Studies, vol. 8 (4), p. 45-78.

Collinson S. (2020). George Floyd. CNN, 10.06.2020 [http: edition.cnn.com/us/live-news/blacklives-matter-protests-george-floyd-06-09-2020; 26.08.2020].

Cuomo C. (2020). America a Tale of Two Cities in Wake of Floyd's Death. CNN, 30.05.2020 [http:www.cnn.com/videos/us/2020/05/30/chris-cuomo-george-floyd-tale-of-two-cities-may28-sot-cpt.cnn; 12.07.2020].

Dubberly S., Griffin E., Mert Bal H. (2015). Making Secondary Trauma a Primary Issue: A Study of Eyewitness Media and Vicarious Trauma on the Digital Frontline [http:www. firstdraftnews. org/wpcontent/uploads/2018/03/trauma_report.pdf?x65316; 20.07.2020].

Ebrahimji A. (2020). This is how loved ones want us to remember George Floyd. CNN, 3.06.2020 [https://edition.cnn.com/2020/05/27/us/george-floyd-trnd/index.html; 17.07.2020].

Figley C.R. (1995). Compassion fatigue as secondary traumatic stress disorder: An overview. In: C.R. Figley (ed.). Compassion Fatigue: Coping with Secondary Traumatic Stress Disorder in Those Who Treat the Traumatized (p. 1-20). Brunner/Mazel Psychological Stress Series, No. 23.

Fountain J.W. (2020). A Modern-Day Lynching. Chicago Sun Times, 5.06.2020 [http:chicago. suntimes.com/columnists/2020/6/5/21282034/george-floyd-killing-lynching-racism-police-brutality-derek-chauvin-john-fountain/; 12.07.2020].

Francisco M. (2020). Personal communication. 
Gerbner G., Gross L. (1976). Living with Television: The Violence Profile. Journal of Communication, vol. 26 (2), p. 1-20.

Gerbner G., Morgan M. (2010). The Mean World Syndrome: Media Violence and the Cultivation of Fear. Media Education Foundation documentary transcript [http://www.mediaed.org/ transcripts/Mean-World-Syndrome-Transcript.pdf/; 19.07.2020].

Glackin-Coley M. (2020). Personal communication.

Gofin L. (2020). Personal communication.

Jamieson E.P., Romer D. (2004). Violence in Popular U.S. Prime Time TV Dramas and the Cultivation of Fear: A Time Series Analysis. Media and Communication, vol. 2 (2), p. 31-41.

Lawless J. (2020). George Floyd's Death an American Tragedy with Global Echoes. US News, $A P, 5.06 .2020$ [http:www.usnews.com/news/world/articles/2020-06-05/george-floyds-deathan-american-tragedy-with-global-echoes; 12.07.2020].

Mueller J. (2020). Personal communication.

O'Handley A. (2017). Tools to reduce Vicarious Trauma/Secondary Trauma and Compassion Fatigue, 3.11.2017 [http:www.tendacademy.ca/tools-to-reduce-vicarious-trauma-secondary-trauma-and-compassion-fatigue; 12.07.2020].

Registered nurse. (2020). Personal communication. The nurse wanted to remain anonymous. Reynolds E. (2020). Candace Owens 'George Floyd is Not My Martyr'. The Federalist, 4.06.2020 [http: thefederalist.com/2020/06/04/candace-owens-george-floyd-is-not-my-martyr; 12.07.2020]. Silver M. (2020). Personal communication.

The Media Education Foundation. (2010). "The Mean World Syndrome: Media Violence \& the Cultivation of Fear”. Documentary by Jeremy Earp et al. Cast: George Gerbner, Michael Morgan [http:vimeo.com/ondemand/11967; 19.07.2020].

Thornton M. (2020). Five Months in: A Timeline of How COVID-19 has unfolded in the US. USA Today, 23.06.2020 [http: www.usatoday.com/in depth/news/nation/2020/04/21/ coronavirus-updates-how-covid-19-unfolded-u-s-timeline; 10.07.2020].

Vera A. (2020). Chicago sees deadliest Memorial Day weekend in four years with 10 killed and 39 injured in shootings within a day of Floyd's death. CNN, 25.05.2020 [http: http:www.cnn. com/2020/05/25/us/chicago-memorial-day-deaths/index.html; 21.09.2020].

Vinney C. (2020). Cultivation Theory, 28.08.2020 [http:www.thoughtco.com/cultivation-theory-definition-4588455; 21.09.2020].

Wiener-Bronner D., Kavilanz P. (2020). Small Businesses Across America Were Struggling to Survive. Now They Face a New Threat. KTBS News, 1.06.2020 [http:www.ktbs.com/news/ national/small-businesses-across-america-were-struggling-to-survive-now-they-face-a-newthreat/article; 17.07.2020].

\section{STRESZCZENIE}

Cyfrowa trauma: Rzeczywistość i zły świat. Medialne relacje z demonstracji ruchu Black Lives Matter podczas pandemii COVID-19 w Stanach Zjednoczonych

Artykuł ma na celu ustalenie, w jakim stopniu materiały rejestrowane przez naocznych świadków, szczególny rodzaj user-generated content, wpływają na dynamikę ruchów 
społecznych i emocje związane z traumą drugiego stopnia / wtórną traumą. W czerwcu 2020 roku, podczas pandemii koronawirusa oraz trwających na ulicach amerykańskich miast demonstracji członków ruchu Black Lives Matter, Autorka przeprowadziła wywiady m.in z aktywistami ruchów społecznych, reporterami, pielęgniarkami pracującymi w Stanach Zjednoczonych. Wypowiedzi respondentów bezpośrednio zaangażowanych w ogólnokrajowe protesty oraz analiza relacji dziennikarskich pozwoliły zweryfikować hipotezę, że filmy rejestrowane przez naocznych świadków wydarzeń oraz medialne relacje odgrywają ważną rolę w kształtowaniu atmosfery strachu i nieufności itp., a sceny nagrane na filmach udostępnianych w internecie mogą prowadzić do wtórnej traumatyzacji odbiorców. Wideo pokazujące śmierć George’a Floyda poruszyło internautów, którzy przesyłali dalej nagranie, które zawierało drastyczne elementy. Nagranie wykonane przez naocznego świadka wydarzeń budziło w respondentach uczucia, które można rozpatrywać w kategoriach wtórnej traumatyzacji. Artykuł ma dwojaką wartość poznawczą: przedstawia aktualny i unikatowy materiał badawczy uzyskany podczas wywiadów z dziennikarzami relacjonującymi protesty oraz aktywistami zaangażowanymi w działalnie ruchów społecznych w USA; ponadto tekst zwraca uwagę na wyzwania, jakie stanęły przed dziennikarzami i pracownikami redakcji podczas pandemii COVID-19. Z przeprowadzonych rozmów wynika, że prawie wszyscy respondenci, którzy widzieli nieocenzurowane nagranie pokazujące śmierć czarnoskórego George’a Floyda, mówili o lęku i emocjach związanych z traumą. Większość rozmówców mówiła o „odrętwieniu” na skutek oglądania drastycznych ujęć, które wydają się czasem zbyt znajome. Respondenci wspominali również o relacjach medialnych, które miały pozytywny wpływ, zachęcający odbiorców do głębszego poznania i zrozumienia historycznego kontekstu ruchu Black Lives Matter. Artykuł pokazuje odczucia, jakie w odbiorcach mediów wywołują drastyczne treści, od których „prawie nie da się uciec” w cyfrowej przestrzeni.

Słowa kluczowe: nagrania naocznych świadków, USA, reporterzy, \#BlackLivesMatter, COVID-19, trauma, cyfrowa trauma, drastyczne treści 